\title{
Perceived Social Support and Assertiveness as a Predictor of Candidates Psychological Counselors' Psychological Well-Being
}

\author{
Bünyamin Ateş ${ }^{1}$ \\ ${ }^{1}$ Faculty of Education, Erzincan University, Erzincan, Turkey \\ Correspondence: Bünyamin Ateş, Faculty of Education, Erzincan University, Erzincan 24000, Turkey. Tel: \\ 90-0446-2240-0894-2152. E-mail: Bunyaminates81@gmail.com
}

Received: March 11, 2016 Accepted: April 17, 2016 Online Published: April 26, 2016

doi:10.5539/ies.v9n5p28 URL: http://dx.doi.org/10.5539/ies.v9n5p28

\begin{abstract}
In this research, to what extent the variables of perceived social support (family, friends and special people) and assertiveness predicted the psychological well-being levels of candidate psychological counselors. The research group of this study included totally randomly selected 308 candidate psychological counselors including 174 females (56.5\%) and 134 males (43.5\%) studying at Erzincan University, Faculty of Education, Psychological Counseling and Guidance Department in 2015-2016 academic year. The age average of the research group was 20.84. Psychological Well-Being Scale, Voltan-Acar Assertiveness Scale, Multidimensional Perceived Social Support Scale, and Personal Information Form were used as the data collection tools in the research. The data obtained in the research were analyzed with stepwise regression analysis method as one of the multiple linear regression analyses methods. According to the research findings, the variables of assertiveness and social support perceived from family, friends and special people significantly predicted psychological well-being.
\end{abstract}

Keywords: assertiveness, psychological counselor candidate, psychological well-being, social support

\section{Introduction}

In terms of historical aspects, negative functioning has been emphasized more than the positive functioning upon psychological health. The absence of a psychological problem has been regarded as the indicator of psychological health. For example, the absence of depression, anxiety or other psychological symptoms has been accepted as the criteria of psychological health. Capacity of people, their positive aspects, and properties related to their well-being, namely positive psychological functionalities of individuals have been ignored (Ryff, 1995; Ryff \& Singer, 1996; Springer \& Hauser, 2006). This has changed in time through the mental health viewpoints focusing on positive functioning of individuals instead of negative functioning, and positive well-being of individuals has been regarded more. Well-being was mentioned as a comprehensive expression of human potential in terms of mental, social, emotional and physical aspects (Ryyf \& Singer, 1998). Well-being includes positive and negative aspects, and life satisfaction components (Ryff \& Keyes, 1995). Several theorists have been noticed to use the properties of well-being in order to express the properties of positive psychological functioning (Ryff, 1989b).

Well-being is a complex structure with optimum experience and functioning. In the literature, there are two types of approaches on well-being. One of these is hedonic approach conceptualized with appreciation and avoiding from pain focusing on happiness. According to this approach, well-being is equal to happiness and satisfaction. In this point of view, well-being covers a wide area from physical satisfaction to the interests. Its conceptual equivalent in psychology is subjective well-being. Subjective well-being can be summarized as happiness as the total of components as life satisfaction, positive mood and negative mood. And Eudaimonic approach defines well-being as individuals' full functioning focusing on meaning and self-realization. Its conceptual equivalent in psychology is psychological well-being (Ryan \& Deci, 2001; Ryff \& Singer, 2008).

Both traditions have concretized humanist values in increasing human capacity in order to analyze what a good life is. Although both of them are the concepts related to well-being, subjective well-being (SWB) that was revealed as result of pursuing a quality living at the end of 1950s was formulated as general life satisfaction and happiness. Subjective well-being (SWB) is evaluation of life in terms of the satisfaction and balance of life between positive and negative effects. Subjective well-being is not only includes emotional indicators (such as happiness) but also cognitive assessments related to life satisfaction. Subjective well-being includes three 
sub-dimensions as positive effects, negative effects and life satisfaction (Keyes, Shmotkin, \& Ryff, 2002).

Psychological well-being (PWB) as another concept related to well-being and expressing a status beyond life satisfaction and happiness was started through the experimental studies in 1980s. Psychological well-being includes the perceptions developed on existential challenges (maintaining the meaningful purposes, personal development, and establishing qualified relationships with the others, etc.) encountered in life. Psychological well-being (PWB) entails the perception of life's relationship with existential challenges. It includes whether the individuals have life purposes or not, whether individuals are aware of their potentials or not, the quality of their relationships with other people, and individuals' feeling responsibility related to their own life. Psychological well-being depends upon clinical and development psychology theories. Psychological well-being is a structure at micro level depending upon providing information related to how individuals evaluate the self and the quality of their life (Keyes, Shmotkin, \& Ryff, 2002; Ryff, Magee, Kling, \& Wing, 1999; Ryff \& Keyes, 1995).

Ryff $(1989 b$, 1995) who pointed out the inadequacy of theoretical explanations related to psychological well-being presented a model on psychological well-being depending upon descriptions and explanations of development, clinic and personality psychologists related to well-being. This model includes Erikson's stages of psychosocial development, Buhler's formulation of basic life tender, Neugarten's descriptions of personality change, Maslow's conception of self-actualization, Rogers's fully functioning person, Jung's formulation of individuation, Allport's conception of maturity, Jahoda's formulation of positive criteria of mental health, and Birren's conception of positive functioning in later life (Ryff, 1989a, 1989b, 1995; Ryff \& Singer, 2008; Vleioras \& Bosma, 2005). Psychological well-being formulated as human development and existential difficulties of life is possible to be expressed as individuals' using their own abilities and capacities at optimum level, and their attempt to feeling good about themselves even when they are aware of their limitations (Keyes, Shmotkin, \& Ryff, 2002).

Ryff presented a model related to psychological well-being with six dimensions. This model includes these: Self-acceptance: It includes being in a positive attitude towards the self, accepting the self in terms of both positive and negative traits, and thinking and feeling positively on past life. Positive relations with others: It includes establishing sincere, satisfactory and fiduciary relationships with the others, establishing strong empathy, sincerity and compassion based relationships with the others, and desiring others to be happy. Autonomy: It includes individuals' making their own decisions, their independence, their resisting against social pressures related to behaving and thinking specifically, shaping their behaviors according to their own inner power, and assessing themselves according to their own personal standards. Environmental mastery: It includes managing the environment and having the feeling of self-efficacy, controlling complex organization of environmental activities, using the environmental opportunities efficiently, personal needs, and creating and choosing contexts in accordance with the values. Purpose in life: It includes the purposes in life, the feeling of managing the life, individuals' beliefs related to the purpose of life, and their noticing the past and now of life. Personal growth: The individuals have the feeling of continuous development. It includes regarding the self as a developing and growing individuals, being open to new experiences, and noticing the self and behaviors as developing, changing and developing efficiently recognizing the self (Ryff \& Singer, 2008; Ryff, Magee, Kling, \& Wing, 1999; Ryff, 1989a, 1989b, 1995; Springer, Hauser, \& Freese, 2006; Springer \& Hauser, 2006).

In the researches carried out upon psychological well-being, several variables possible to be efficient upon psychological well-being of individuals were noticed to be present. Some of these variables included social competence (Holopainen, Lappalainen, Junttila, \& Savolainen, 2012), self-respect, self-confidence (Sandhu, Singh, Tung, \& Kundra, 2012), personality traits such as neuroticism, extroversion and openness (Kokko, Tolvanen \& Pulkkinen, 2013), emotional intelligence (James, Bore, \& Zito, 2012), social network (Park, Song, \& Lee, 2014), optimism (Souri \& Hasanirad, 2011), religion and religiousness (Green \& Elliott, 2010; Unterrainer, Ladenhauf, Moazedi, Wallner-Liebmann, \& Fink, 2010), employment, level of education, marriage, age and gender (Khumalo, Temane, \& Wissing, 2012), and physical health (Shields \& Price, 2005). In addition to these variables, the social support perceived from different sources was noticed to be efficient upon psychological well-being of individuals (Brough \& Pears, 2004; Daniels \& Guppy, 1997; Du, Li, Chi, Zhao, \& Zhao, 2015; Silverstein, Chen, \& Heller, 1996).

The concept of social support that is possible to be positively efficient upon psychological well-being of individuals has grabbed the attention of researchers since the mid-1970s (G. Zimet, Dahlem, S. Zimet, \& Farley, 1988). Social support can be defined as the resources provided to the individuals by the others (Cohen \& Syme, 1985). Social support can also be defined as the help provided to the individuals by the individuals creating the social network. For that reason, social support creates the functional dimension of social network (Martínez-Hernáez, Carceller-Maicas, DiGiacomo, \& Ariste, 2016). Social support can be generally categorized 
into different types as emotional, instrumental, informational and evaluation support (Kef, 1997; Langford, Bowsher, Maloney, \& Lillis, 1997; Wong et al., 2014). Families, friends and other special people create the most important social support sources of individuals (You \& Lu, 2014; Zimet, Dahlem, Zimet, \& Farley, 1988).

In the literature, two models have been noticed to be suggested on social support. One of these is Buffering model. According to this model, social support has a function protecting the individuals against the effects of stressful events. And the second is basic effect model. According to this model, social support has positive and beneficial effect upon the individuals at any case whether they are stressful or not (Cohen \& Syme, 1985; Cohen \& Wills, 1985). In the research carried out previously, it was noticed that social support decreased depression (Brausch \& Decker, 2014), stress (Çivitci, 2015), suicide attempt (Miller, Esposito-Smythers, \& Leichtweis, 2015), shyness and solitude (Zhao, Kong, \& Wang, 2013); and increased self-respect (Tian, Liu, Huang \& Huebner, 2013), life quality (Cohen, 2013; Hamren, Chungkham, \& Hyde, 2015), social competence perception (Traş \& Arslan, 2013) and academic success (Yıldırım, 2006).

Beside the social support, assertiveness as a social skill has been considered to be efficient upon psychological well-being. The concept of assertiveness was defined by Alberti and Emmons (2002) as a type of behavior enabling individuals to act in accordance with their own interests considering equality in personal relationships, to defense the self, to express their feelings easily, and to use their own rights violating the rights of others.

The individuals with assertive type of behavior consider the requests and needs of the others while meeting their own requests and needs. Assertive individuals express their requests, needs and thoughts clearly without violating the rights of others. Assertive type of behavior includes honest and transparent expression of thoughts, feelings, beliefs, preferences, and requests, the skill of saying "no" against an unwanted situation or request, the thought of "win-win" in interpersonal relationships, respecting to the self and the others, being flexible, accepting the success and mistakes, listening efficiently, realistic expectations, and equality in relationships, etc. (Alberti \& Emmons, 2002; Bishop, 2013; Garner, 2012; Michelli, 2012; Pfeiffer, 2010; Potter, 2007).

In accordance with the aforementioned information, it was noticed that various variables were possible to be efficient upon psychological well-being. In the studies carried out in abroad, there were studies in which psychological well-being and social support were discussed together; however, there were limited number of such studies carried out in Turkey. Moreover, no studies were found in the literature discussing psychological well-being and assertiveness together. It has been considered that psychological well-being of human qualified as a social being cannot be considered as independent from the social support and assertiveness as a social skill. When this study was considered in terms of the research group (candidate psychological counselors), although there were studies related to different research groups on psychological well-being in Turkey and in abroad, no studies carried out upon candidate psychological counselors that would render psychological counseling service in the future were noticed. In general of the previous studies, the groups receiving psychological service were focused; however, candidate psychological counselors who would render these services were noticed not to be focused. In this sense, the result to be obtained in the study was considered to be important and beneficial in terms of grabbing the attraction towards the subject and candidate psychological counselors' mental health.

In reference to the aforementioned information, it was aimed in this study to what extent the variables of perceived social support (family, friends and special person) and assertiveness predicted the psychological well-being levels of candidate psychological counselors. Depending upon this purpose, the answer was sought to the question of "Do the variables of perceived social support (family, friends and social person) and assertiveness significantly predict psychological well-being levels of candidate psychological counselors?" Upon this problem sentence, sub-problems of this study were created as such: a) To what extent do the variables of perceived social support (family, friends, social person) and assertiveness predict psychological well-being together? b) How much strength does each of these variables predict the psychological well-being levels of candidate psychological counselors? c) What is the importance order of these variables in predicting the psychological well-being?

\section{Method}

\subsection{Research Model}

The research was a descriptive study on screening model which analyzed to what extent the variables of perceived social support (family, friends and special person) and assertiveness predicted the psychological well-being levels of candidate psychological counselors.

\subsection{Research Group}

The research group of this study included totally randomly selected 308 candidate psychological counselors 
including 174 females (56.5\%) and 134 males (43.5\%) studying at Erzincan University, Faculty of Education, Psychological Counseling and Guidance Department in 2015-2016 academic year. The age average of the research group was 20.84 .

\subsection{Data Collection Tools}

\subsubsection{Psychological Well-Being Scale}

Psychological Well-Being Scale was developed by Diener et al. (2009-2010). The scale was adapted into Turkish by Telef $(2011 ; 2013)$. As result of the exploratory factor analysis, total explained variance was determined to be $42 \%$. Factor loads of the scale items were calculated between .54 and .76 . In confirmatory factor analysis, fit index values were found as RMSEA $=0.08, \mathrm{SRMR}=0.04, \mathrm{GFI}=0.96, \mathrm{NFI}=0.94, \mathrm{RFI}=0.92, \mathrm{CFI}=0.95$ and IFI=0.95. In terms of Psychological Well-Being Scale was found to have a relationship with autonomy as one of the sub-dimensions of psychological well-being scales at the level of .30, with environmental mastery at the level of .53 , with the positive relations with others at the level of .41 , with the purpose in life at the level of .38, with self-acceptance at the level of .56, and with total psychological well-being at the level of .56. Moreover, Psychological Well-being Scale was found to have a relationship with autonomy as one of the sub-dimensions of Need Satisfaction Scale at the level of .30, with adequacy at the level of .69, with being relevant at the level of .57 , and with total need satisfaction at the level of .73. Cronbach Alpha internal consistency coefficient obtained in reliability study of the scale was calculated as .80 . According to test-retest result, high level of positive and significant relationship was found between the first and second implementations $(r=0.86, p<.001)$. Item total correlation of the psychological well-being scale was noticed to be varied between .41 and .63 , and $\mathrm{t}$-values were determined to be significant $(p<.001)$. Items of the psychological well-being scale were answered between 1 and 7 as I Totally Disagree (1) and I Totally Agree (7). All items were expressed as positive. The scores ranged from 8 to 56 . The high score indicated the individuals to have several psychological sources and power. In this study, Cronbach Alpha reliability coefficient was determined to be .85 .

\subsubsection{Voltan-Acar Assertiveness Scale}

Voltan-Acar Assertiveness Scale was developed by Voltan-Acar and Öğretmen (2007) for university students in order to measure the assertiveness levels of the individuals. In the scale, there were totally 28 items including 17 items for the dimension of shyness and 11 items for the dimension of assertiveness. The scale was on six-point Likert type. The reactions varied between "Very much like me-1" and "Very much like me-6." The lowest score to be taken from the scale was 28 , and the highest score was 168 . As the score the individuals could take from the scale increased, the level of assertiveness increased. According to the confirmatory factor analysis results of the assertiveness inventory, internal consistency reliability coefficients of the sub-dimensions provided to be valid were 0.83 for shyness dimension (17 items) and 0.78 for assertive dimension (11 items). Cronbach Alpha reliability of the assertiveness scale was calculated to be 0.87 . Test-retest reliability of the test (28 items) was observed to be 0.89 . In this study, Cronbach Alpha reliability coefficient of the scale was determined to be .80 .

\subsubsection{Multidimensional Perceived Social Support Scale}

The scale was developed by Zimet et al. (1988) in order to evaluate the perceptions of individuals related to the adequacy of social support received from their families, friends and the special people in their life. The scale was adapted into Turkish by Eker, Arkar, and Yaldız (2001). The scale included 12 items, and three sub-scales as family $\left(3^{\text {rd }}, 4^{\text {th }}, 8^{\text {th }}, 11^{\text {th }}\right.$ items $)$, friends $\left(6^{\text {th }}, 7^{\text {th }}, 9^{\text {th }}, 12^{\text {th }}\right.$ items $)$ and special people $\left(1^{\text {st }}, 2^{\text {nd }}, 5^{\text {th }}, 10^{\text {th }}\right.$ items $)$. Furthermore, total score of the scale was possible to be determined adding the sub-dimension scores. The Likert type scale was scored between 1 and 7, and score of the scale's sub-dimensions varied between 4 and 28, and total score of the scale varied between 12 and 84 . Highness of the obtained score indicated the highness of the perceived social support. As result of the factor analysis performed for the construct validity, 3 factors were revealed; Cronbach Alpha internal consistency coefficient of the scale was determined to be .89 for whole scale, to be .85 for family support dimension, to be .88 for friend support dimension, and to be .92 for special person support dimension, and the obtained values were determined to be high (Eker, Arkar, \& Yaldız, 2001). In this study, Cronbach Alpha internal consistency coefficient of the scale was determined to be .89 for whole scale, to be .87 for family support dimension, to be .84 for friend support dimension, and to be .80 for special person support dimension.

\subsubsection{Personal Information Form}

Within the scope of the research, the form was developed by the researcher in order to obtain personal information of the candidate psychological counselors creating the research group of the study. 


\subsection{Collection of Data}

Data collection tools used in the research was performed to the candidate psychological counselors in groups by the researcher. Before administering the data collection tools to the groups, the participants were informed about the purpose of the research. In each group, implementation lasted for 45 minutes.

\subsection{Data Analysis}

In the research, normality and linearity of the data sets were primarily evaluated in order to determine whether the data were appropriate for Multiple Linear Regression analysis or not. Whether there were extreme values complicating the normality (multivariable) and linearity assumptions or not was analyzed according to Mahalanobis distance value (18.47), and Cook's $\left(\right.$ Cook' $\left.^{\prime}<1\right)$ and Leverage Values (.000-.020). Furthermore; kurtosis, skewness values, scattering and histogram graphics of the data sets were also investigated. The data of 14 participants were excluded from the data set because they had extreme values at a level affecting the data analysis. The sample size was also noticed to be at an adequate number when considering the number of predicting variables beside data set's providing linearity and normality conditions. Zero-order correlation coefficient, tolerance value, VIF and CI values between the predicting variables were also investigated for the condition of having no high correlation between the predicting variables as another assumption of multiple regression analysis. It was determined for the predicting variables that there was no correlation value over .80 possible to be defined as multiple correlation between the predicting variables (Table 1), the tolerance value was over .20, VIF value was below 10, and CI value was lower than 30. Finally, Durbin-Watson value was investigated in order to analyze the condition of errors' being independent, and the value was determined to be between 1 and 3 ( $\mathrm{DW}=1.84$ ), and not creating a problem.

Depending upon these processes, obtained data were specified to be appropriate for the multiple linear regression analysis. The data obtained in the research were investigated through stepwise regression analysis method as one of the multiple linear regression analysis methods. The significance level of .05 was considered to be acceptable in the research (Akbulut, 2010; Büyüköztürk, 2011; Seçer, 2015).

\section{Findings}

In this section, the relationships between the predicted variable (psychological well-being) and the predicting variables (assertiveness and social support perceived from family, friends and special person) were primarily investigated (Table 1). Subsequently, stepwise regression analysis as one of the multiple linear regression analysis methods was performed, and the results were presented in Table 2.

Table 1. Correlation coefficients related to the psychological well-being, assertiveness and social support perceived from family, friends, and special person

\begin{tabular}{lccccc}
\hline & PWB & Family & Friend & $\begin{array}{l}\text { Special } \\
\text { Person }\end{array}$ & Assertiveness \\
\hline PWB & 1 & & & & \\
\hline Family & $.512^{* *}$ & 1 & & & \\
\hline Friend & $.473^{* *}$ & $.493^{* *}$ & 1 & 1 & 1 \\
\hline Special Person & $.371^{* *}$ & $.284^{* *}$ & $.559^{* *}$ & $.245^{* *}$ & \\
\hline Assertiveness & $.286^{* *}$ & $.222^{* *}$ & $.380^{* *}$ & & \\
\hline
\end{tabular}

$* *$ P $<.01$ PWB (Psychological Well-Being).

When Table 1 was analyzed, positive significant relationships were determined between psychological well-being and assertiveness and social support perceived from family, friends and special person.

When ANOVA table testing the significance of predicted variables' explanation value of the change and the relationship of predicting variables with the predicted variable was analyzed, explained variance or the regression model was determined to be statistically significant $(\mathrm{p}<.01)$. $\mathrm{F}$ values related to ANOVA table were presented in Table $2\left(\mathrm{~F}_{1 / 306}=108.57 ; \mathrm{F}_{2 / 305}=73.78 ; \mathrm{F}_{3 / 304}=52.60 ; \mathrm{F}_{4 / 303}=40.94 ; \mathrm{p}<.01\right)$. According to this, predicting variables successfully fulfilled prediction process on the model.

When Table 2 was analyzed, because stepwise regression analysis significantly predicted psychological well-being, the variables of assertiveness and social support perceived from family, friend and special person 
were determined to be processed during the stepwise regression analysis process. When both Beta values and partial and zero-order correlation coefficients were analyzed, positive and significant level of relationships were determined between psychological well-being and the variables of assertiveness, social support perceived from family, friend and special person. Both the variables of assertiveness and social support perceived from family, friend and special person explained approximately $35 \%$ of total variance related to psychological well-being of candidate psychological counselors $\left(\mathrm{R}=.592 ; \mathrm{R}^{2}=.351 ; \mathrm{P}<.01\right)$.

Table 2. Stepwise multiple regression analysis results related to the prediction of psychological well-being

\begin{tabular}{|c|c|c|c|c|c|c|c|c|c|c|}
\hline \multirow[t]{2}{*}{ Model } & \multicolumn{6}{|c|}{ Correlations } & \multirow[b]{2}{*}{$\mathrm{R}$} & \multirow[b]{2}{*}{$\mathrm{R}^{2}$} & \multirow[b]{2}{*}{$\mathrm{F}$} & \multirow[b]{2}{*}{$\mathrm{df}$} \\
\hline & $B$ & Std. Error & Beta & $\mathrm{t}$ & Zero-Order & Partial & & & & \\
\hline 1 (Constant) & 18.32 & 1.96 & & $9.30^{* *}$ & & & \multirow{2}{*}{$.512^{\mathrm{a}}$} & \multirow{2}{*}{.262} & \multirow{2}{*}{$108.57^{* *}$} & \multirow{2}{*}{$1 / 306$} \\
\hline Family & .914 & .088 & .512 & $10.42^{* *}$ & .512 & .512 & & & & \\
\hline 2 (Constants) & 12.55 & 2.16 & & $5.79 * *$ & & & \multirow{3}{*}{$.571^{\mathrm{b}}$} & \multirow{3}{*}{.326} & \multirow{3}{*}{$73.78^{* *}$} & \multirow{3}{*}{$2 / 305$} \\
\hline Family & .658 & .097 & .368 & $6.81 * *$ & .512 & .364 & & & & \\
\hline Friend & .549 & .102 & .291 & $5.38^{* *}$ & .473 & .295 & & & & \\
\hline 3 (Constants) & 11.47 & 2.18 & & $5.25 * *$ & & & \multirow{4}{*}{$.585^{\mathrm{c}}$} & \multirow{4}{*}{.342} & \multirow{4}{*}{$52.60^{* *}$} & \multirow{4}{*}{$3 / 304$} \\
\hline Family & .655 & .096 & .366 & $6.85^{* *}$ & .512 & .366 & & & & \\
\hline Friend & .392 & .117 & .208 & $3.35 * *$ & .473 & .189 & & & & \\
\hline SP & .233 & .087 & .151 & $2.68 * *$ & .371 & .152 & & & & \\
\hline 4 (Constants) & 8.95 & 2.49 & & $3.59 * *$ & & & \multirow{5}{*}{$.592^{\mathrm{d}}$} & \multirow{5}{*}{.351} & \multirow{5}{*}{$40.94^{* *}$} & \multirow{5}{*}{$4 / 303$} \\
\hline Family & .646 & .095 & .362 & $6.79 * *$ & .512 & .364 & & & & \\
\hline Friend & .327 & .120 & .173 & $2.72 * *$ & .473 & .154 & & & & \\
\hline SP & .225 & .086 & .146 & $2.61 * *$ & .371 & .148 & & & & \\
\hline Assertiveness & .053 & .026 & .104 & $2.07 *$ & .286 & .118 & & & & \\
\hline
\end{tabular}

Beta coefficient of the variable of social support perceived from family that was analyzed in the first step of stepwise regression analysis was .512 in predicting psychological well-being of candidate psychological counselors. T-test results related to the significance of Beta coefficient were found to be significant $(\mathrm{P}<.01)$. The variable of social support perceived from family solely explained approximately $26 \%$ of psychological well-being of candidate psychological counselors $\left(\mathrm{R}=.512 ; \mathrm{R}^{2}=.262\right)$.

In the second step of stepwise regression analysis, the variable of social support perceived from friends was included into the variable of social support perceived from the family. When the other variables affecting he psychological well-being were kept as constant, the variables of social support perceived from family and friends together explained approximately $33 \%$ of psychological well-being of candidate psychological counselors $\left(\mathrm{R}=.571 ; \mathrm{R}^{2}=.326\right)$. When the other variables in the model were kept as constant, Beta coefficient of the variable of social support perceived from the family was .368 , and Beta coefficient of the social support variable perceived from friends was .291. T-test results related to the significance of Beta coefficient were determined to be significant $(\mathrm{P}<.01)$.

In the third step of stepwise regression analysis, the variable of social support perceived from special person was included in the variable of social support perceived from family and friends into the model. When the other variables affecting psychological well-being were kept as constant, the variables of social support perceived from family, friends and special person explained approximately $34 \%$ of psychological well-being of candidate psychological counselors together $\left(\mathrm{R}=.585 ; \mathrm{R}^{2}=.342\right)$. When the other variables in the model were kept as constant, Beta coefficient of the variable of social support perceived from the family was .366, Beta coefficient of the social support variable perceived from friends was .208, and Beta coefficient of the social support variable perceived from special person was .151. T-test results related to the significance of Beta coefficient were determined to be significant $(\mathrm{P}<.01)$. 
In the fourth step of stepwise regression analysis, the variable of assertiveness was included in the variable of social support perceived from family, friends and special person into the model. When the other variables affecting psychological well-being were kept as constant, the variables of assertiveness and social support perceived from family, friends and special person explained approximately $35 \%$ of psychological well-being of candidate psychological counselors together $\left(\mathrm{R}=.592 ; \mathrm{R}^{2}=.351\right)$. When the other variables in the model were kept as constant, Beta coefficient of the variable of social support perceived from the family was .362 , Beta coefficient of the social support variable perceived from friends was .173, Beta coefficient of the social support variable perceived from special person was .146, and Beta coefficient of the assertiveness variable was .104. T-test results related to the significance of Beta coefficient were determined to be significant $(\mathrm{P}<.01 ; \mathrm{P}<.05)$.

According to Beta coefficients of the variables included into the model in the fourth step and t-test results related to the significance of Beta coefficients, the variables of assertiveness and social support perceived from family, friend and special person significantly predicted psychological well-being. When regression coefficients (Beta) and t-values related to the variables in the model were considered, "social support perceived from the family" significantly predicted psychological well-being of candidate psychological counselors at the first rank, "social support perceived from the friends" predicted at the second rank, "social support perceived from special person" predicted at the third rank, and "assertiveness" predicted at the fourth rank. In other words, relative importance order of the predicting variables upon psychological well-being was social support perceived from family, friend, special person, and assertiveness, respectively.

\section{Conclusion, Discussion and Suggestions}

At the end of the study, positive significant relationships were determined between psychological well-being of candidate psychological counselors and assertiveness and social support perceived from family, friend, and special person. Furthermore, the variables of assertiveness and social support perceived from family, friends and special person were significant predictors of psychological well-being variable. Both the variables of assertiveness and social support perceived from family, friend and special person explained approximately $35 \%$ of total variance related to psychological well-being of candidate psychological counselors. "Social support perceived from the family" significantly predicted psychological well-being of candidate psychological counselors at the first rank, "social support perceived from the friends" predicted at the second rank, "social support perceived from special person" predicted at the third rank, and "assertiveness" predicted at the fourth rank.

According to obtained findings, the variable of social support candidate psychological counselors perceived from the family was an important and significant predictor of psychological well-being variable, and there was a positive significant relationship between the variables. In this sense, the variable of social support perceived from the family was possible to be mentioned as positively affecting psychological well-being of candidate psychological counselors. Candidate psychological counselors' perceiving emotional, instrumental, informational, etc. support from their families and their perceiving this support at a high level provided a positive contribution upon their psychological well-being. In this sense, the social support perceived from family was remarkable upon candidate psychological counselors' high level psychological well-being. On this subject, similar results were also noticed in the literature ( $\mathrm{Du}, \mathrm{Li}$, Chi, J. Zhao, \& G. Zhao, 2015; Stenfert, Kroese, Hussein, Clifford, \& Ahmed, 2002; Wang \& Castañeda-Sound, 2008). When the results of this study were analyzed, as the social support level perceived from family increased, the psychological well-being levels was noticed to be increased, as well. Depending upon both the results of this study and the results of other studies, it was considered that increasing the awareness levels of families upon social support was remarkable for increasing the psychological well-being levels of candidate psychological counselors.

Beside the variable of social support perceived from the family, the variable of social support perceived from the friends was an important and second-rank predictor of psychological well-being variable, and there was a positive significant relationship between the variables. This finding was consistent with the findings of the studies carried out by Cicognani (2011), Ekas, Lickenbrock, and Whitman (2010), Malkoç and Yalçın (2015), H. Winefield, A. Winefield, and Tiggemann (1992). When the results of this study and other studies were evaluated together, the social support perceived from friends was noticed to have a positive significant effect upon the psychological well-being. In this sense, candidate psychological counselors' perceiving high level social support from their friends during the university education could provide an increase at their psychological well-being levels. Maybe the most important social support for candidate psychological counselors to maintain their university process in a successful and qualified was of their friends. At this point, qualified friendly relationships and the social support perceived from them have been considered to be important and efficient in terms of psychological well-being. In this sense, including activities and studies increasing the level of social support 
perceived from friends and qualified friendship relations related to the university students was considered as important for the psychological well-being.

According to the findings obtained at the end of the research, beside the variable of social support perceived from the family and friends, the variable of social support perceived from the special person was an important and third-rank predictor of psychological well-being variable, and there was a positive significant relationship between the variables. The special person included people such as girl/boyfriend, fiancé, relative, neighbor, and doctor, etc. except from the family and friends (Eker, Arkar, \& Yaldız, 2001). In reference to this finding of the research, when developmental periods of the candidate psychological counselors were considered, the social support perceived from family and friends as well as the social support perceived from special person were efficient upon their psychological well-being levels. Apart from family and friends, perceiving adequate support from other social sources including the socially supportive relationships established with the opposite sex and the relationships established before marriage was considered to be significant in terms of psychological well-being. In literature review, it was noticed that high level social support and social support perceived from the special person as a sub-dimension positively affected psychological well-being levels of individuals (Brough \& Pears, 2004; Daniels \& Guppy, 1994; Okawa et al., 2011; Silverstein, Chen \& Heller, 1996; Turner, 1981). To summarize the result of this study shortly, no matter which source the social support is perceived, high level social support perception created a positive effect upon psychological well-being of candidate psychological counselors. At this point, one way of increasing the psychological well-being levels of candidate psychological counselors was to increase social support perceived from different sources.

According to the result of this research, beside the variable of perceived social support (family, friends, special person), the variable of assertiveness was an important and fourth-rank predictor of psychological well-being variable, and there was a positive significant relationship between the variables. In literature review, the variable of psychological well-being was noticed to be analyzed with different variables (Brough \& Pears, 2004; Kokko, Tolvanen, \& Pulkkinen, 2013; Park, Song, \& Lee, 2014; Shields \& Price, 2005). However, no studies analyzing psychological well-being and assertiveness were found. Candidate psychological counselors at university education process have been expected to take their own decisions and responsibilities, create efficient and permanent solutions against the problems, and meet their requests and needs. These could be indicator of candidate psychological counselors' having assertive behavior. A candidate psychological counselor is considered to have assertive behavior skills in terms of being efficient and adequate in terms of their profession and personal development. A candidate psychological counselor with these skills can meet the requests as being aware of the rights of the self and the others avoiding from shy and offensive behaviors. Psychological well-being level of a candidate psychological counselor with such skills is expected to be affected positively from this. The result of this study confirmed this expectation. As result of this study, the suggestions below were offered:

- This study was carried out with candidate psychological counselors studying at Erzincan University, Faculty of Education, Psychological Counseling and Guidance department. A similar study can also be carried out with different research groups.

- In this study, perceived social support and assertiveness were discussed as the predictors of psychological well-being. Different variables related to psychological well-being can also be discussed.

- Further studies increasing the social support perceptions and assertiveness of candidate psychological counselors can also be carried out in terms of the mental health (seminars, group activities, psycho-educational studies, instrumental support and informational support opportunities, etc.).

- These subjects can be emphasized more in psychological counseling and guidance service activities in different educational grades.

\section{References}

Akbulut, Y. (2010). Sosyal bilimlerde SPSS uygulamaları. İstanbul: İdeal Kültür Yayıncılık.

Alberti, R., \& Emmons, M. (2002). Kendinize yatırım yapın, atılganlık (Çev. Katlan, S.). Ankara: HYB Yayıncilik.

Bishop, S. (2013). Develop your assertiveness. USA: Kogan Page.

Brausch, A. M., \& Decker, K. M. (2014). Self-esteem and social support as moderators of depression, body image, and disordered eating for suicidal ideation in adolescents. Journal of Abnormal Child Psychology, 42(5), 779-789. http://dx.doi.org/10.1007/s10802-013-9822-0 
Brough, P., \& Pears, J. (2004). Evaluating the influence of the type of social support on job satisfaction and work related psychological well-being. International Journal of Organisational Behaviour, 8(2), 472-485.

Büyüköztürk, Ş. (2011). Sosyal bilimler için veri analizi el kitabı (15. Baskı). Ankara: Pegem Akademi Yayıncilık.

Cicognani, E. (2011). Coping strategies with minor stressors in adolescence: Relationships with social support, self-efficacy, and psychological well-being. Journal of Applied Social Psychology, 41(3), 559-578. http://dx.doi.org/10.1111/j.1559-1816.2011.00726.x

Cohen, S. D. (2013). Social support interventions will improve the quality of life of ESRD patients. Seminars in Dialysis, 26(3), 262-265. http://dx.doi.org/10.1111/sdi.12064

Cohen, S., \& Syme, S. L. (1985). Issues in the study and application of social support. Social Support and Health, 3, 3-22.

Cohen, S., \& Wills, T. A. (1985). Stress, social support, and the buffering hypothesis. Psychological Bulletin, 98(2), 310-357. http://dx.doi.org/10.1037/0033-2909.98.2.310

Çivitci, A. (2015). The moderating role of positive and negative affect on the relationship between perceived social support and stress in college students. Educational Sciences: Theory \& Practice, 15(3), 565-573. http://dx.doi.org/10.12738/estp.2015.3.2553

Daniels, K., \& Guppy, A. (1994). Occupational stress, social support, job control, and psychological well-being. Human Relations, 47(12), 1523-1544. http://dx.doi.org/10.1177/001872679404701205

Daniels, K., \& Guppy, A. (1997). Stressors, locus of control, and social support as consequences of affective psychological well-being. Journal of Occupational Health Psychology, 2(2), 156-174. http://dx.doi.org/10.1037/1076-8998.2.2.156

Du, H., Li, X., Chi, P., Zhao, J., \& Zhao, G. (2015). Relational self-esteem, psychological well-being, and social support in children affected by HIV. Journal of Health Psychology, 20(12), 1568-1578. http://dx.doi.org/10.1177/1359105313517276

Ekas, N. V., Lickenbrock, D. M., \& Whitman, T. L. (2010). Optimism, social support, and well-being in mothers of children with autism spectrum disorder. Journal of Autism and Developmental Disorders, 40(10), 1274-1284. http://dx.doi.org/10.1007/s10803-010-0986-y

Eker, D., Arkar, H., \& Yaldız, H. (2001). Çok boyutlu algılanan sosyal destek ölçeği'nin gözden geçirilmiş formunun faktör yapısı, geçerlik ve güvenirliği. Türk Psikiyatri Dergisi, 12(1),17-25.

Garner, E. (2012). Assertiveness. Denmark: Ventus Publishing.

Green, M., \& Elliott, M. (2010). Religion, health, and psychological well-being. Journal of Religion and Health, 49(2), 149-163. http://dx.doi.org/10.1007/s10943-009-9242-1

Hamren, K., Chungkham, H. S., \& Hyde, M. (2015). Religion, spirituality, social support and quality of life: Measurement and predictors CASP-12 (v2) amongst older Ethiopians living in Addis Ababa. Aging \& Mental Health, 19(7), 610-621. http://dx.doi.org/10.1080/13607863.2014.952709

Holopainen, L., Lappalainen, K., Junttila, N., \& Savolainen, H. (2012). The role of social competence in the psychological well-being of adolescents in secondary education. Scandinavian Journal of Educational Research, 56(2), 199-212. http://dx.doi.org/10.1080/00313831.2011.581683

James, C., Bore, M., \& Zito, S. (2012). Emotional intelligence and personality as predictors of psychological well-being. Journal of Psychoeducational Assessment, 30(4), 425-438. http://dx.doi.org/10.1177/0734282912449448

Kef, S. (1997). The personal networks and social supports of blind and visually impaired adolescents. Journal of Visual Impairment \& Blindness, 91(3), 236-244.

Keyes, C. L., Shmotkin, D., \& Ryff, C. D. (2002). Optimizing well-being: the empirical encounter of two traditions. Journal of Personality and Social Psychology, 82(6), 1007-1022. http://dx.doi.org/10.1037/0022-3514.82.6.1007

Khumalo, I. P., Temane, Q. M., \& Wissing, M. P. (2012). Socio-demographic variables, general psychological well-being and the mental health continuum in an African context. Social Indicators Research, 105(3), 419-442. http://dx.doi.org/10.1007/s11205-010-9777-2

Kokko, K., Tolvanen, A., \& Pulkkinen, L. (2013). Associations between personality traits and psychological 
well-being across time in middle adulthood. Journal of Research in Personality, 47(6), 748-756. http://dx.doi.org/10.1016/j.jrp.2013.07.002

Langford, C. P. H., Bowsher, J., Maloney, J. P., \& Lillis, P. P. (1997). Social support: A conceptual analysis. Journal of Advanced Nursing, 25(1), 95-100. http://dx.doi.org/10.1046/j.1365-2648.1997.1997025095.x

Malkoç, A., \& Yalçın, İ. (2015). Üniversite öğrencilerinde psikolojik dayanıklılık, sosyal destek, başa çıkma ve iyi-oluş arasındaki ilişkiler. Türk Psikolojik Danışma ve Rehberlik Dergisi, 5(43), 35-43.

Martínez-Hernáez, A., Carceller-Maicas, N., DiGiacomo, S. M., \& Ariste, S. (2016). Social support and gender differences in coping with depression among emerging adults: A mixed-methods study. Child and Adolescent Psychiatry and Mental Health, 10(1), 1-11. http://dx.doi.org/10.1186/s13034-015-0088-x

Michelli, D. (2012). Successful assertiveness. London: Hodder Education.

Miller, A. B., Esposito-Smythers, C., \& Leichtweis, R. N. (2015). Role of social support in adolescent suicidal ideation and suicide attempts. Journal of Adolescent Health, 56(3), 286-292. http://dx.doi.org/10.1016/j.jadohealth.2014.10.265

Okawa, S., Yasuoka, J., Ishikawa, N., Poudel, K. C., Ragi, A., \& Jimba, M. (2011). Perceived social support and the psychological well-being of AIDS orphans in urban Kenya. AIDS Care, 23(9), 1177-1185. http://dx.doi.org/10.1080/09540121.2011.554530

Park, N., Song, H., \& Lee, K. M. (2014). Social networking sites and other media use, acculturation stress, and psychological well-being among East Asian college students in the United States. Computers in Human Behavior, 36, 138-146. http://dx.doi.org/10.1016/j.chb.2014.03.037

Pfeiffer, R. (2010). Relationships: Assertiveness skills. USA: Growth Publishing.

Potter, J. V. (2007). Assertiveness, individuation \& autonomy. USA: AFS Publishing.

Ryan, R. M., \& Deci, E. L. (2001). On happiness and human potentials: A review of research on hedonic and eudaimonic well-being. Annual Review of Psychology, 52(1), 141-166. http://dx.doi.org/10.1146/annurev.psych.52.1.141

Ryff , D. C. \& Singer, B. (1998). The contours of positive human health. Psychological Inquiry, 9(1), 1-28. http://dx.doi.org/10.1207/s15327965pli0901_1

Ryff, C. D. (1989a). Beyond Ponce de Leon and life satisfaction: New directions in quest of successful ageing. International Journal of Behavioral Development, 12(1), 35-55. http://dx.doi.org/10.1177/016502548901200102

Ryff, C. D. (1989b). Happiness is everything, or is it? Explorations on the meaning of psychological well-being. Journal of Personality and Social Psychology, 57(6), 1069-1081. http://dx.doi.org/10.1037/0022-3514.57.6.1069

Ryff, C. D. (1995). Psychological well-being in adult life. Current Directions in Psychological Science, 4(4), 99-104. http://dx.doi.org/10.1111/1467-8721.ep10772395

Ryff, C. D., \& Keyes, C. L. M. (1995). The structure of psychological well-being revisited. Journal of Personality and Social Psychology, 69(4), 719-727. http://dx.doi.org/10.1037/0022-3514.69.4.719

Ryff, C. D., \& Singer, B. (1996). Psychological well-being: Meaning, measurement, and implications for psychotherapy research. Psychotherapy and Psychosomatics, 65(1), 14-23. http://dx.doi.org/10.1159/000289026

Ryff, C. D., \& Singer, B. H. (2008). Know thyself and become what you are: A eudaimonic approach to psychological well-being. Journal of Happiness Studies, 9(1), 13-39. http://dx.doi.org/10.1007/s10902-006-9019-0

Ryff, C. D., Magee, W. J., Kling, K. C., \& Wing, E. H. (1999). Forging macro-micro linkages in the study of psychological well-being. In C. D. Ryff, \& J. W.Magee (Eds.), The self and society in aging processes (pp 247-278). Springer Publishing Company: New York.

Sandhu, D., Singh, B., Tung, S., \& Kundra, N. (2012). Adolescent identity formation, psychological well-being, and parental attitudes. Pakistan Journal of Psychological Research, 27(1), 89-105.

Seçer, İ. (2015). SPSS ve LISREL ile pratik veri analizi (2. Baskı) Ankara: Anı Yayıncılık.

Shields, M. A., \& Price, S. W. (2005). Exploring the economic and social determinants of psychological 
well-being and perceived social support in England. Journal of the Royal Statistical Society: Series A (Statistics in Society), 168(3), 513-537. http://dx.doi.org/10.1111/j.1467-985X.2005.00361.x

Silverstein, M., Chen, X., \& Heller, K. (1996). Too much of a good thing? Intergenerational social support and the psychological well-being of older parents. Journal of Marriage and the Family, 58(4), 970-982. http://dx.doi.org/10.2307/353984

Souri, H., \& Hasanirad, T. (2011). Relationship between resilience, optimism and psychological well-being in students of medicine. Procedia-Social and Behavioral Sciences, 30, 1541-1544. http://dx.doi.org/10.1016/j.sbspro.2011.10.299

Springer, K. W., \& Hauser, R. M. (2006). An assessment of the construct validity of Ryff's scales of psychological well-being: Method, mode, and measurement effects. Social Science Research, 35(4), 1080-1102. http://dx.doi.org/10.1016/j.ssresearch.2005.07.004

Springer, K. W., Hauser, R. M., \& Freese, J. (2006). Bad news indeed for Ryff's six-factor model of well-being. Social Science Research, 35(4), 1120-1131. http://dx.doi.org/10.1016/j.ssresearch.2006.01.003

Stenfert Kroese, B., Hussein, H., Clifford, C., \& Ahmed, N. (2002). Social support networks and psychological well-being of mothers with intellectual disabilities. Journal of Applied Research in Intellectual Disabilities, 15(4), 324-340. http://dx.doi.org/10.1046/j.1468-3148.2002.00128.x

Telef, B. B. (2011). Psikolojik iyi oluş ölçeği (PIOO): Türkçeye uyarlama, geçerlik ve güvenirlik çalışması. 11. Psikolojik Danışma ve Rehberlik Kongresi, 3-5 Ekim, Selçuk- İzmir.

Telef, B. B. (2013). Psikolojik iyi oluş ölçeği (PIOO): Türkçeye uyarlama, geçerlik ve güvenirlik çalışması. Hacettepe Eğitim Fakültesi Dergisi, 28(3), 374-384.

Tian, L., Liu, B., Huang, S., \& Huebner, E. S. (2013). Perceived social support and school well-being among Chinese early and middle adolescents: The mediational role of self-esteem. Social Indicators Research, 113(3), 991-1008. http://dx.doi.org/10.1007/s11205-012-0123-8

Traş, Z., \& Arslan, E. (2013). An investigation of perceived social support and social self efficacy in adolescents. Elementary Education Online, 12(4), 1133-1140.

Turner, R. J. (1981). Social support as a contingency in psychological well-being. Journal of Health and Social Behavior, 22(4), 357-367. http://dx.doi.org/10.2307/2136677

Unterrainer, H. F., Ladenhauf, K. H., Moazedi, M. L., Wallner-Liebmann, S. J., \& Fink, A. (2010). Dimensions of religious/spiritual well-being and their relation to personality and psychological well-being. Personality and Individual Differences, 49(3), 192-197. http://dx.doi.org/10.1016/j.paid.2010.03.032

Vleioras, G., \& Bosma, H. A. (2005). Are identity styles important for psychological well-being? Journal of Adolescence, 28(3), 397-409. http://dx.doi.org/10.1016/j.adolescence.2004.09.001

Voltan-Acar, N., \& Öğretmen, T.(2007). Kendini belirleme (güvengenlik) ölçeği geliştirme çalışmaları. Türk Psikolojik Danışma ve Rehberlik Dergisi, 3(27), 67-78.

Wang, C. C. D., \& Castañeda-Sound, C. (2008). The role of generational status, self-esteem, academic self-efficacy, and perceived social support in college students' psychological well-being. Journal of College Counseling, 11(2), 101-118. http://dx.doi.org/10.1002/j.2161-1882.2008.tb00028.x

Winefield, H. R., Winefield, A. H., \& Tiggemann, M. (1992). Social support and psychological well-being in young adults: The multi-dimensional support scale. Journal of Personality Assessment, 58(1), 198-210. http://dx.doi.org/10.1207/s15327752jpa5801_17

Wong, A. G., Ki, P., Maharaj, A., Brown, E., Davis, C., \& Apolinsky, F. (2014). Social support sources, types, and generativity: A focus group study of cancer survivors and their caregivers. Social Work in Health Care, 53(3), 214-232. http://dx.doi.org/10.1080/00981389.2013.873515

Yıldırım, İ. (2006). Akademik başarının yordayıcısı olarak gündelik sıkıntılar ve sosyal destek. Hacettepe Üniversitesi Eğitim Fakültesi Dergisi, 30, 258-267.

You, J., \& Lu, Q. (2014). Sources of social support and adjustment among Chinese cancer survivors: gender and age differences. Supportive Care in Cancer, 22(3), 697-704. http://dx.doi.org/10.1007/s00520-013-2024-z

Zhao, J., Kong, F., \& Wang, Y. (2013). The role of social support and self-esteem in the relationship between shyness and loneliness. Personality and Individual Differences, 54(5), 577-581. http://dx.doi.org/10.1016/j.paid.2012.11.003 
Zimet, G. D., Dahlem, N. W., Zimet, S. G., \& Farley, G. K. (1988). The multidimensional scale of perceived social support. Journal of Personality Assessment, $32(1), \quad 30-41$. http://dx.doi.org/10.1207/s15327752jpa5201_2

\section{Copyrights}

Copyright for this article is retained by the author(s), with first publication rights granted to the journal.

This is an open-access article distributed under the terms and conditions of the Creative Commons Attribution license (http://creativecommons.org/licenses/by/3.0/). 